\title{
Isolation of lupeol from Grewia lasiocarpa stem bark: Antibacterial, antioxidant, and cytotoxicity activities
}

\author{
NNEKA AKWU`, YOUGASPHREE NAIDOO, MOGANAVELLI SINGH, \\ SADASHIVA CHANNANGIHALLI THIMMEGOWDA, NIRASHA NUNDKUMAR, JOHNSON LIN \\ School of Life Sciences, University of KwaZulu-Natal. Pitlochry Rd, Dawncrest, Westville, 3629, Durban 4000, South Africa. \\ Tel.: +27-31-2608317, `email:akwu.nk@gmail.com
}

Manuscript received: 27 July 2020. Revision accepted: 13 November 2020.

\begin{abstract}
Akwu N, Naidoo Y, Singh M, Thimmegowda SC, Nundkumar N, Lin J. 2020. Isolation of lupeol from Grewia lasiocarpa stem bark: Antibacterial, antioxidant, and cytotoxicity activities. Biodiversitas 21: 5684-5691. Lupeol a pentacyclic triterpenoid, was extracted from the stem bark of Grewia lasiocarpa. Stem bark was macerated with chloroform $\left(\mathrm{CHCl}_{3}\right)$ at $25 \pm 2{ }^{\circ} \mathrm{C}$, and then purified using a silica gel column. The mobile phase was hexane (100\%) and hexane: ethyl acetate (80:20) as the mobile phase. The structure of lupeol was identified by ${ }^{1} \mathrm{HNMR}$, and ${ }^{13} \mathrm{C}$ NMR spectral data, compared with reported data. The antibacterial, antioxidant and cytotoxicity activities of lupeol were evaluated using agar-well diffusion against six clinic bacteria isolates, namely Escherichia coli (ATCC 25922), Pseudomonas aeruginosa (ATCC 27853), Klebsiella pneumoniae (ATCC 314588), and Salmonella typhimurium (ATCC 14026) Gram-positive bacteria: Staphylococcus aureus (ATCC 25923), methicillin-resistant Staphylococcus aureus (MRSA) (ATCC BAA-1683). The antioxidants assays were performed using 2,2-diphenyl-1-picrylhydrazyl (DPPH) and ferric reducing antioxidant power (FRAP). Cytotoxicity activity was carried out by MTT (3-(4,5-dimethylthiazol)-2,5-diphenyl tetrazolium bromide) assay was carried out against HEK293 (human embryonic kidney), HeLa (cervical carcinoma), and MCF-7 (breast adenocarcinoma) cell lines. The concentration range of lupeol was $240-15 \mu \mathrm{g} / \mathrm{mL}$. Lupeol at the concentration of $240 \mathrm{and} 120 \mu \mathrm{g} / \mathrm{mL}$ have no antibacterial activity against Methicillin-resistant Staphylococcus aureus (MRSA) (ATCC BAA-1683). The antioxidant activity was dose-dependent, while cytotoxic activities were observed in HEK293, HeLa, and MCF-7 cells. This study was the first report on the extraction, isolation, and biological activities of lupeol, from the stem bark of G. lasiocarpa.
\end{abstract}

Keywords: Antibacterial, antioxidant, cytotoxicity, Grewia lasiocarpa, lupeol, stem bark

\section{INTRODUCTION}

Grewia lasiocarpa E. Mey. ex Harv. (Malvaceae) is a deciduous, fast-growing tropical shrub or small tree that usually grows on marginal soils (Boon and Pooley 2010). Species of this genus have been known to have numerous medicinal properties (Goyal 2012; Ullah et al. 2012; Sidhu and Zafar 2020) i.e., antibacterial, antimalarial, antifertility, antifungal, antioxidant, antiviral, antidiabetic, antipyretic, anti-inflammatory, anthelmintic, radioprotective, analgesic and hepatoprotective (Zia-Ul-Haq et al. 2012; Sinha et al. 2015; Shukla et al. 2016; Dwivedi and Manigauha 2017; Oribayo et al. 2018; Pramodini et al. 2018). However, $G$. lasiocarpa has been reported to have medicinal and nutritive properties (Akwu et al. 2019a, b, c).

The history of medicinal plant selection is usually based on the data of ethnopharmacology, ethnobotany, folkloric systems, or chemotaxonomic studies (Cordell 2015; Da et al. 2015; Alamgir 2017). These historical findings gave rise to phytochemistry, which is the study of the chemistry of phytochemical compounds. This study includes the direct isolation and identification of phytochemical compounds and their bioactivity evaluation (in vitro and in vivo) (Altemimi et al. 2017).

Globally, there has been a disproportionate increase in the rate of diseases/health problems and the number of new drugs being developed to combat diseases and resistance causative organisms (WHO 2011; Thirugnanasambandan and Kannayiram 2016; Weekes 2020). At present, there is a worldwide surge in the development of new drugs, particularly from medicinal plants (Altemimi et al. 2017; Ghosh et al. 2020). Physiological and biochemical processes in the human body are influenced by external and internal factors, which affect the production of free radicals and other reactive oxygen species. The external factors are exposure to industrial chemicals, radiations from ozone and $\mathrm{x}$-rays, tobacco smoke, other air pollutants, while the internal factors involve the metabolic breakdown in the human body (Lobo et al. 2010; Juturu and Gormley 2013; Papadopoulou et al. 2020). Several advances in the study of free radicals and reactive oxygen species (ROS) have tremendously elevated the management of health and diseases because of their scavenging activity, i.e., cellular necrosis caused by auto-oxidation of cellular membrane lipids (Arung et al. 2018; Chen et al. 2018). Cancer is the leading disease in developed countries (Bajoriniene et al. 2019; Teoh et al. 2019).

Several alkaloids have been isolated from several Grewia spp., namely G. bicolor, G. biloba, G. damine, G. bilamellata. These alkaloids are harman, 6methoxyharman, 6-hydroxyharman, triterpenes (friedelin, epi-friedelan-3-ol), flavones (vitexin and isovitexin), neolignans $\quad(8-\mathrm{O}-4$ '-neolignanguaiacylglycerol- $\beta$-coniferyl ether (erythro), 8-04'-neolignanguaiacylglycerol- $\beta$-coniferyl 
ether(threo) (Jaspers et al. 1986, Jayasinghe et al. 2004, Ma et al. 2006). However, there is no information to date on the isolation, identification, and biological activities of any compound from the stem bark of G. lasiocarpa. Hence, our investigation was directed towards the isolation and identification of any compounds from the stem bark of $G$. lasiocarpa. Hence, our investigation was directed towards the isolation and identification of a chemical compound from the crude chloroform extract of G. lasiocarpa stem bark and investigate the antioxidant, antibacterial, and cytotoxicity activities of the isolated compound.

\section{MATERIALS AND METHODS}

\section{Plant materials}

The plant material (stem bark) of Grewia lasiocarpa was collected from the Umdoni Trust park, KwaZuluNatal. Dr. Syd Ramdhani carried out identification as a curator. A voucher specimen (Nneka 002) was deposited in the Herbarium of the School of Life Sciences, University of KwaZulu-Natal, Durban, South Africa. The stem bark was dried, pulverized using a Waring blender, and stored in airtight amber storage before extraction.

\section{Extraction and isolation}

Approximately, $1100 \mathrm{~g}$ powder of $G$. lasiocarpa stem bark was subjected to a sequential extraction by increasing polarity using hexane $\left(\mathrm{C}_{6} \mathrm{H}_{14}\right)$, chloroform $\left(\mathrm{CHCl}_{3}\right)$ and methanol $(\mathrm{MeOH})$. The maceration was done at $25 \pm 2{ }^{\circ} \mathrm{C}$ at 160-200 rpm. The extracts were concentrated under reduced pressure using a rotary evaporator and dried in a drying room at room temperature.

\section{Column chromatography (CC)}

The isolation of the pure compound from the crude chloroform extract was carried out by column chromatography using silica gel 60 mesh size 70-230 (E. Merck, $0.063-0.200 \mathrm{~mm}$ ) as a stationary phase, with gradient elution using $n$-hexane $(100 \%)$ and $n$-hexane and ethyl acetate (80:20).

\section{Structural elucidation of the isolated compound}

The isolated compound was structurally elucidated by Nuclear Magnetic Resonance (NMR) spectroscopic analysis on a Bruker Avance ${ }^{\mathrm{III}} 400 \mathrm{MHz}$ spectrophotometer (Germany) at room temperature. About $25 \mathrm{mg}$ of the pure compound was mixed with $700 \mu \mathrm{L}$ of deuterated chloroform $\left(\mathrm{CDCl}_{3}\right)$ (Merck, Darmstadt, Germany). The 1D NMR $\left({ }^{1} \mathrm{H}\right.$ and ${ }^{13} \mathrm{C}$ NMR) and DEPT, and $2 \mathrm{D}$ experiments (HSQC, HMBC, COSY, NOESY) were conducted. The NMR spectra were obtained under normal conditions and recorded at high resolution developed at $22^{\circ} \mathrm{C}$ using tetramethylsilane (TMS) as an internal reference.

Gas Chromatography-Mass Spectrometry (GC-MS) analysis

In a previous study, the crude chloroform extract of $G$. lasiocarpa stem bark was analyzed using gas chromatography unit (GCMS-QP2010 Plus Shimadzu) with a $30 \mathrm{~m} \times 0.25 \mathrm{~mm}$ ID $\times 0.25 \mu \mathrm{m}$ film thickness of a
$5 \%$ phenyl methyl siloxane capillary column. The carrier gas was helium, and $2 \mu \mathrm{L}$ of the extract was injected (splitless) with a column flow rate of $1.21 \mathrm{~mL} / \mathrm{min}$; Injection temperature and interface temperature were $240^{\circ} \mathrm{C}$, and $220^{\circ} \mathrm{C}$, respectively. The initial column temperature was $50^{\circ} \mathrm{C}$ held for $1.5 \mathrm{~min}$, then increased to $300^{\circ} \mathrm{C}$ at a rate of $10^{\circ} \mathrm{C} / \mathrm{min}$, then held for $7 \mathrm{~min}$, with a run time of $60 \mathrm{~min}$ within the scan range 40 to $500 \mathrm{~m} / \mathrm{z}$.

\section{Biological evaluation: In vitro antibacterial, antioxidant, and cytotoxicity assays \\ In vitro antibacterial assay}

The purified compound at the concentration range of $15-240 \mu \mathrm{g} / \mathrm{mL}$ was also evaluated for its ability to inhibit the growth of six pathogenic bacteria i.e., Gram-negative bacteria (Escherichia coli (ATCC 25922), Pseudomonas aeruginosa (ATCC 27853), Klebsiella pneumoniae (ATCC 314588) and Salmonella typhimurium (ATCC 14026); and Gram-positive bacteria: Staphylococcus aureus (ATCC 25923), methicillin-resistant Staphylococcus aureus (MRSA) (ATCC BAA-1683). The bacteria isolates were provided by Dr. Chunderika Mocktar, School of Pharmacy and Pharmacology, University of KwaZulu-Natal. The antibacterial assay was performed using the agar well diffusion method, with slight modifications (Perez et al., 1990). The inoculated Müller-Hinton agar plates were incubated at $37^{\circ} \mathrm{C}$ for $18-24 \mathrm{~h}$, and the zones of inhibition were measured after the incubation period. Gentamicin and streptomycin were used as the positive controls at a concentration of $10 \mu \mathrm{g} / \mathrm{mL}$ for the Gram-negative and Gram-positive bacteria, respectively. The assay was performed in triplicate.

\section{In vitro antioxidant assay}

DPPH free radical scavenging activity. The hydrogen donating ability of the pure compound was determined using a modified 2,2-diphenyl-1-picrylhydrazyl (DPPH) spectrophotometric assay as described by Braca et al. (2002). Briefly, $30 \mu \mathrm{L}$ of the pure compound at a concentration range of $15-240 \mu \mathrm{g} / \mathrm{mL}$ was pipetted into a 96-well microplate in triplicate. After that, $150 \mu \mathrm{L}$ of 0.3 $\mathrm{mM}$ DPPH solution was added into each well. The microplate was incubated in the dark at $25^{\circ} \mathrm{C}$ for $30 \mathrm{~min}$. The absorbance of the pure compound was measured at $517 \mathrm{~nm}$, and the percentage of the free radical inhibition was used to express the free radical scavenging activity. Ascorbic acid was used as the standard. The $\mathrm{IC}_{50}$ was derived from the inhibition curves by plotting the percentage inhibition against the concentration logarithmic scale. The free radical scavenging ability of pure compound was calculated using equation 1 :

DPPH scavenging activity $(\%)=\left[\frac{\left(\mathrm{Abs}_{\mathrm{control}}-\mathrm{Abs}_{\text {sample }}\right)}{\mathrm{Abs}_{\text {control }}}\right] * 100$

Where;

Abs control is the absorbance of DPPH and methanol

Abs sample is the absorbance of DPPH radical + sample (compound or standard) 
Ferric reducing antioxidant power (FRAP) assay. The ferric reducing power of the pure compound was determined using a modified FRAP assay as described by Benzie and Strain (1996). Briefly, $50 \mu \mathrm{L}$ of $0.2 \mathrm{M}$ sodium phosphate buffer (pH 6.6) and $100 \mu \mathrm{L}$ of $1 \%$ potassium ferricyanide were added to $50 \mu \mathrm{L}$ of the pure compound at a concentration range of $15-240 \mu \mathrm{g} / \mathrm{mL}$. The microplate was incubated at $50^{\circ} \mathrm{C}$ for $30 \mathrm{~min}$. After incubation, each well was added with $50 \mu \mathrm{L}$ of $10 \%$ trichloroacetic acid, 50 $\mu \mathrm{L}$ of distilled water and $10 \mu \mathrm{L}$ of $0.1 \%$ iron (III) chloride (FeCl3), and homogenized. Thereafter, $200 \mu \mathrm{L}$ of the homogenized solution was transferred to a 96 well microplate, and the absorbance was measured at $700 \mathrm{~nm}$. The results were expressed as a percentage of the absorbance of the crude extracts to that of gallic acid using the formula (equation 2):

$\%$ inhibition $=($ Abs of sample $/$ Abs of garlic acid $) \times 100$

Where; Abs: absorbance

\section{Cell viability assessment by MTT assay}

The MTT cell viability assay using the HEK293, HeLa, and MCF-7 cells was carried out as described by Mosmann (1983). The HEK293 (human embryonic kidney) cells were obtained from The University of Witwatersrand Medical School, South Africa, HeLa (cervical carcinoma) and MCF-7 (breast adenocarcinoma) cells were purchased from ATCC, Manassas, USA.

The cells were trypsinized upon $90 \%$ confluency and seeded into a 48-well plate at a density of $3 \times 10^{4}$ cells/well. The cells were incubated at $37^{\circ} \mathrm{C}$ for $24 \mathrm{~h}$ for attachment. After the incubation, the media was changed, and the different concentrations of compound (15-240 $\mu \mathrm{g} / \mathrm{mL}$ ) was added to the wells. The plates were incubated again for $48 \mathrm{~h}$ at $37^{\circ} \mathrm{C}$. After that, the media was changed, and $200 \mu \mathrm{L}$ of fresh medium containing $20 \mu \mathrm{L}$ of MTT (5 $\mathrm{mg} / \mathrm{mL}$ in phosphate-buffered saline (PBS)) was added and cells incubated for four hours. The media containing the MTT reagent was then removed and $200 \mu \mathrm{L}$ DMSO was quickly added to solubilize the formazan crystals. The absorbance was read at $540 \mathrm{~nm}$ using a Mindray MR-96A microplate reader (Vacutec, Hamburg, Germany). All assays were performed in triplicate, using untreated cells as a control.

\section{Statistical analysis}

The data were analyzed using EXCEL and SPSS 25 for Windows, IBM Corporation, New York, USA. Data obtained were expressed as mean \pm standard deviation. Pvalues of $<0.05$ were considered significant. All analyses were performed in triplicate. $(n=3)$.

\section{RESULTS AND DISCUSSION}

Lupeol is usually found in fruit waxes, leaves, and stem bark (Sánchez-Burgos et al. 2015; Vithana et al. 2019; Jahan and Makbul 2020). It has been isolated from the stem of Grewia asiatica (Chattopadhyay and Pakrashi 1975), stem bark of Grewia optiva (Uddin et al. 2013), whole plant of Grewia bicolor (Jaspers et al. 1986), the root bark of Grewia rothi (Bhagat and Misra 1974), roots and stem bark of Grewia tiliaefolia (Badami et al. 2004).

A previous study revealed that lupeol was present in the crude stem bark chloroform extract of $G$. lasiocarpa (Akwu et al. 2019c) with a retention time of lupeol $\left(\mathrm{C}_{30} \mathrm{H}_{50} \mathrm{O}\right)$, as evidenced by a molecular ion peak $\mathrm{m} / \mathrm{z} 426$ $[\mathrm{M}]^{+}$was $29.20 \mathrm{~min}$ (Figure 1A). However, Soujanya et al. (2017) reported a retention time of 27.16, 28.57, and 28.15 . The NMR spectral ${ }^{1} \mathrm{H}$ NMR spectrum and ${ }^{13} \mathrm{CNMR}$ (Figures 1.B and 1.C) respectively, revealed that the isolated compound is lupeol with the chemical structure as depicted in Figure 2.E (Silva 2017; Beserra et al. 2018, Gurupriya et al. 2018; Balde et al. 2019). The NMR spectroscopic, structural analyses confirmed that the isolated compound (1) is lupeol (Figures 1.A, 1.B, and 2.AD) and the chemical structure, as illustrated in Figure 2.E. Compound (1): white powder, ${ }^{1} \mathrm{H}$ NMR $\left(\mathrm{CDCl}_{3}, 400 \mathrm{MHz}\right)$ $\delta: 4.57$ (s, H-29a), 4.68(s, H-29b), $3.20(1 \mathrm{H}, \mathrm{dd}, \mathrm{J}=5.12$; $11.27 \mathrm{~Hz}, \mathrm{H}-3)$, 1.68, 1.02, 0.98, 0.96, 0.82, 0.76, 0.70 (21 $\mathrm{H}, 7 \mathrm{~s}, 7 \mathrm{CH}_{3}$ ) (Figure 2). ${ }^{13} \mathrm{C} \mathrm{NMR}\left(\mathrm{CDCl}_{3}, 400 \mathrm{MHz}\right) \delta$ : 38.7 (C-1), 27.3 (C-2), 79.0 (C-3), 38.7 (C-4), 55.3 (C-5), 18.3 (C-6), 34.2 (C-7), 40.9 (C-8), 50.4 (C-9), 37.1 (C-10), 20.8 (C-11), 25.23 (C-12), 38.8 (C-13), 42.7 (C-14), 27.4 (C-15), 34.2 (C-16), 42.7 (C-17), 48.3 (C-18), 48.7 (C-19), 150.4 (C-20), 29.7 (C-21), 40.9 (C-22), 27.9 (C-23), 15.3 (C-24), 16.1 (C-25), 15.9 (C-26), 14.7 (C-27), 18.3 (C-28), 109.6 (C-29), 19.0 (C-30). It could be proposed that the molecular formula is $\mathrm{C}_{30} \mathrm{H}_{50} \mathrm{O}$. The ${ }^{1} \mathrm{H}$ NMR spectrum showed seven tertiary methyl singlets at $\delta 0.70,0.76,0.82$, $0.96,0.98,1.02,1.68$, and one secondary hydroxyl group as a doublet of doublets at $\delta 3.20$. It also showed two olefinic protons at $\delta 4.57$ and 4.68 representing the exocyclic double bond as in 1 . The ${ }^{13} \mathrm{C}$ NMR spectrum of the compound showed 30 signals for the terpenoid of the lupine, Skeleton, which included a carbon bonded to the hydroxyl group at C-3 position appearing at $\delta$ 79.01. The olefinic carbons of the exocyclic double bond appearing at $\delta 150.48$ and 109.69. Therefore, structure (1) was assigned as lupeol. Other similar spectral data have been reported (Jain and Bari 2010; Moradkhani et al. 2014; Amoussa et al. 2016). Lupeol has been reported to possess antioxidant, antimicrobial, anti-tumor, and anti-carcinogenic activities (Wal et al. 2011; Ogunlaja 2017; Kumari et al. 2018; Swargiary et al. 2020).

A previous study by Amoussa et al. (2016) showed that lupeol at $100 \mu \mathrm{g} /$ disc was not effective in inhibiting the growth of Pseudomonas aeruginosa; Staphylococcus epidermidis; Candida albicans, and Enterococcus faecalis. The antibacterial activity result of this study (Table 1) showed that Pseudomonas aeruginosa was resistant to lupeol. A study by Patel et al. (2018) showed that lupeol inhibits the growth of $P$. aeruginosa at concentrations of 25-5 $\mu \mathrm{g} / \mathrm{mL}$. However, this study showed that only methicillin-resistant Staphylococcus aureus (MRSA) was insignificantly susceptible to lupeol compared to positive control (Table 1). This insignificant activity was following the result by Gallo and Sarachine (2009). The disparities in the inhibition against $P$. aeruginosa from this study, Amoussa et al. (2016) and Patel et al. (2018) may be attributed to the genetic differences that may exist between bacteria strains of the same genus and species. 


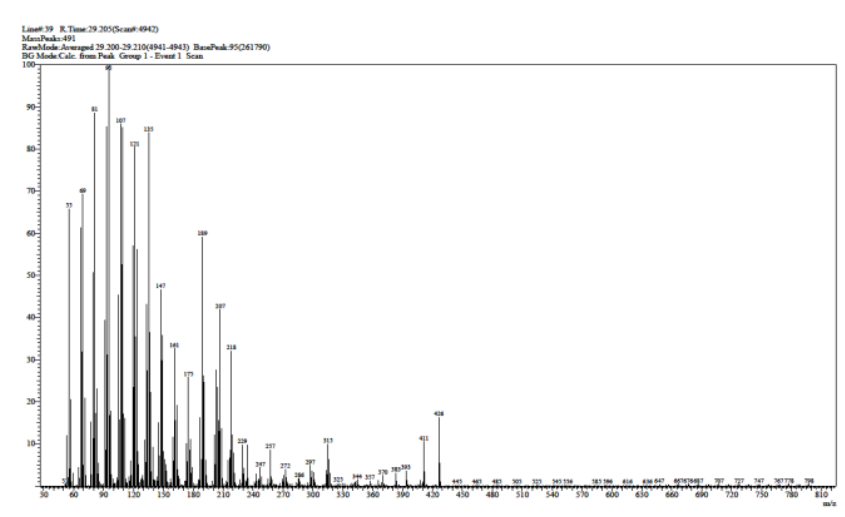

Figure 1A. GC-MS chromatograph of lupeol

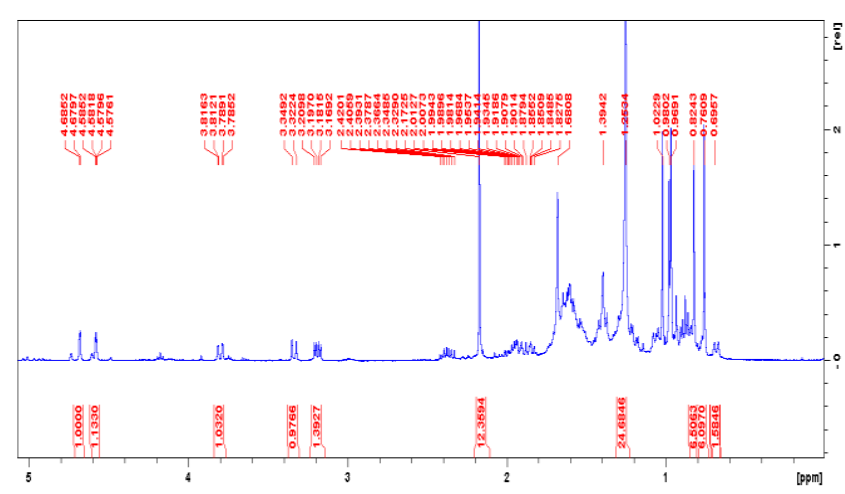

Figure 1B. ${ }^{1} \mathrm{H}$ NMR spectrum of lupeol in $\mathrm{CDCl}_{3}$.

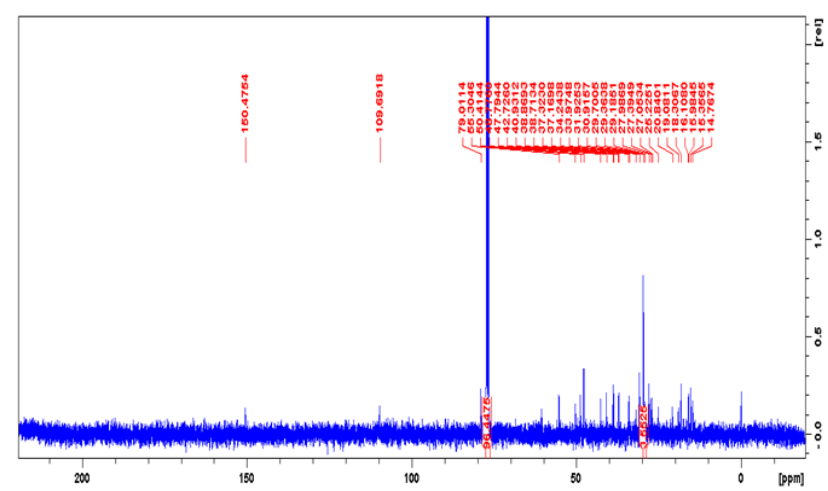

Figure 1C. ${ }^{13} \mathrm{CNMR}$ spectrum of lupeol in $\mathrm{CDCl}_{3}$

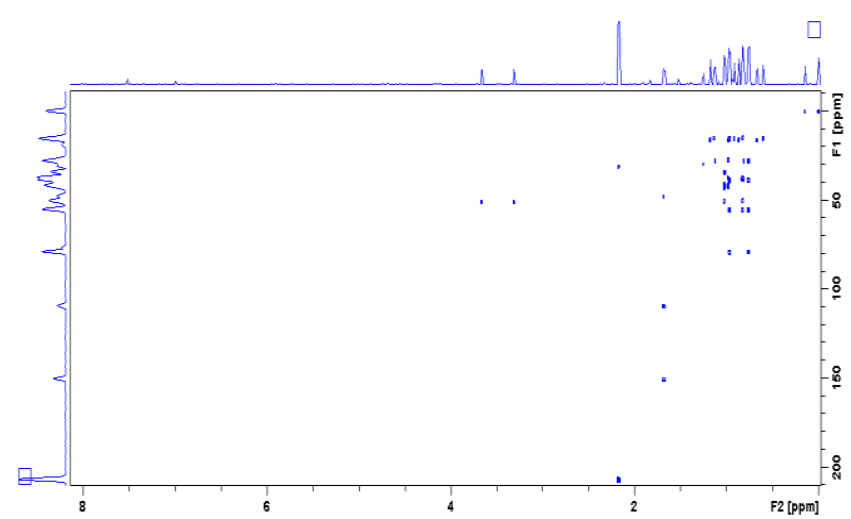

Figure 2A. HMBC $\left(\mathrm{CDCl}_{3}, 400 \mathrm{MHz}\right)$ of compound (1) lupeol isolated from the stem bark of Grewia lasiocarpa

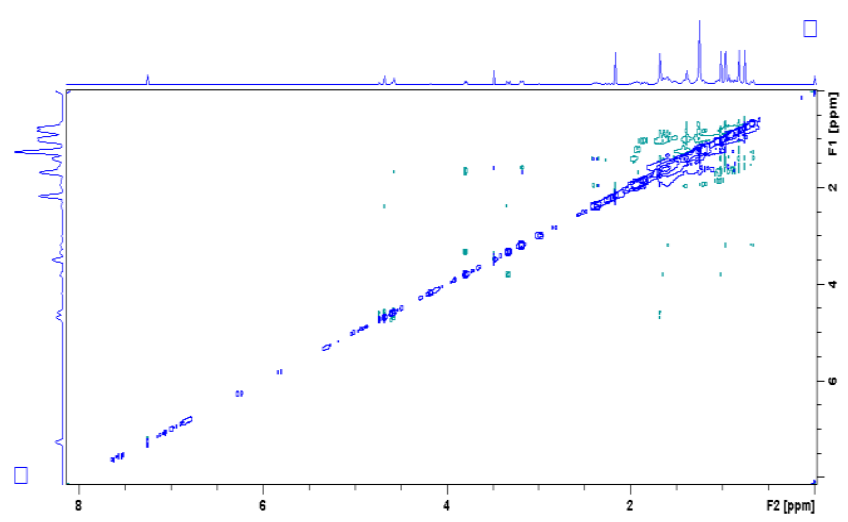

Figure 2B. NOESY $\left(\mathrm{CDCl}_{3}, 400 \mathrm{MHz}\right)$ of compound (1) lupeol isolated from the stem bark of Grewia lasiocarpa

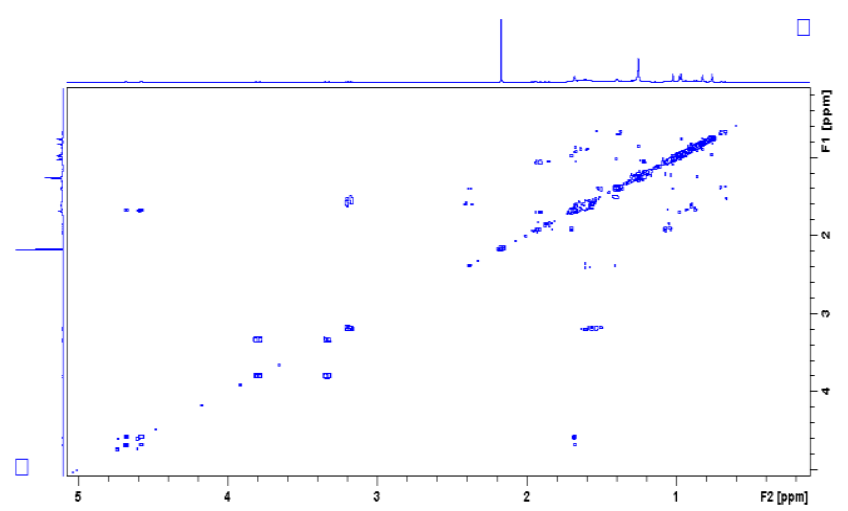

Figure 2C. COSY $\left(\mathrm{CDCl}_{3}, 400 \mathrm{MHz}\right)$ of compound (1) lupeol isolated from the stem bark of Grewia lasiocarpa

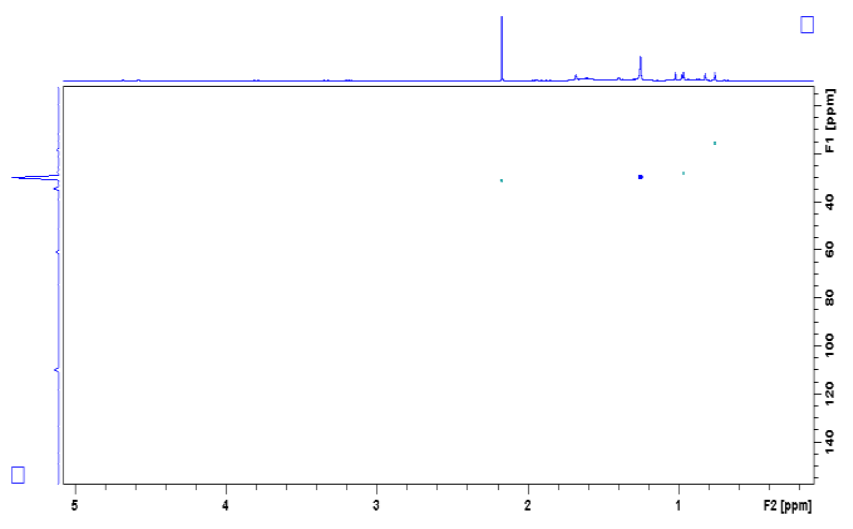

Figure 2D. HSQC $\left(\mathrm{CDCl}_{3}, 400 \mathrm{MHz}\right)$ of compound (1) lupeol isolated from the stem bark of Grewia lasiocarpa

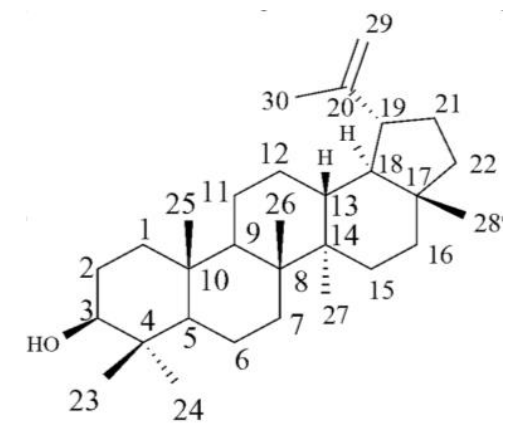

Figure 2E. Chemical structure of lupeol 


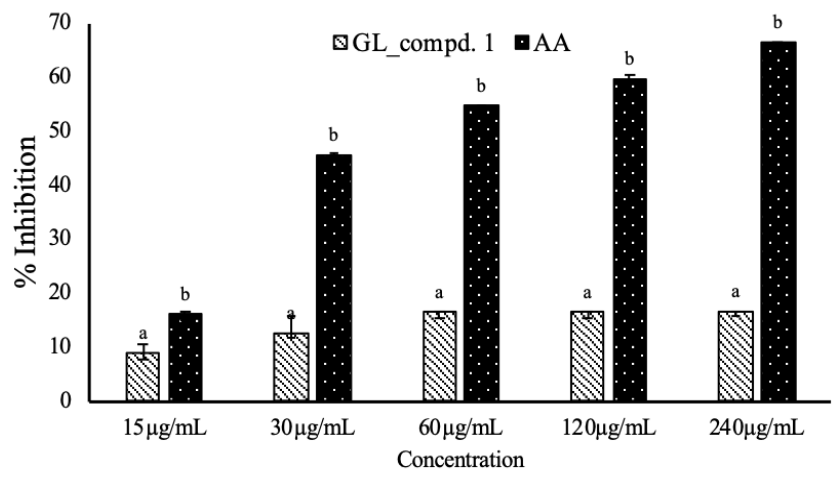

Figure 3.A. DPPH Free radical scavenging activity of compound (1) isolated from the stem bark of Grewia lasiocarpa at various concentrations. ${ }^{\mathrm{a}}$ and $\mathrm{b}$ letters above the bars for a given concentration are significantly different between treatment (Tukey's honest significant difference multiple range post hoc test $\mathrm{p}<0.05$ IBM SPSS version 25). GL: Grewia lasiocarpa, AA: Ascorbic acid, compd.1: compound.

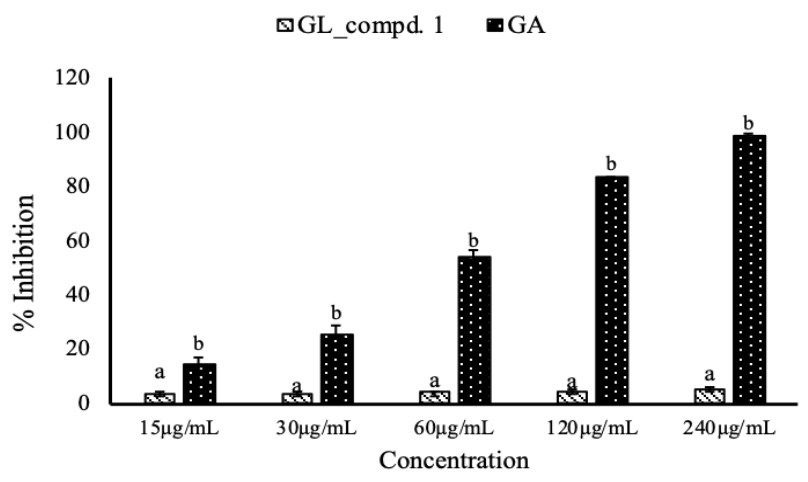

Figure 3.B. Ferric Reducing Antioxidant Power values of compound (1) isolated from the stem bark of Grewia lasiocarpa at various concentrations. ${ }^{a-b}$ letters above the bars for a given concentration are significantly different between treatment other (Tukey's honest significant difference multiple range post hoc test $p<0.05$ IBM SPSS version 25). GL: Grewia lasiocarpa, GA: gallic acid.

\section{田 HEK293}

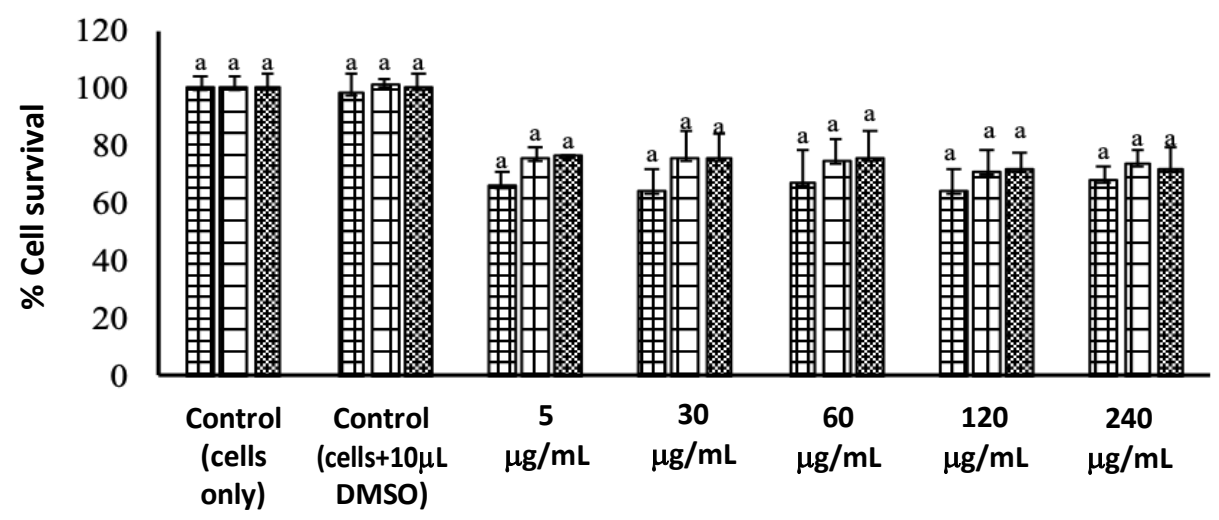

Figure 4. Effect of lupeol on viability on HEK293, HeLa and MCF-7 cell lines (MTT cell viability assay). Data is represented as mean $\pm \mathrm{SD}(n=3)$. ${ }^{a}$ letter above the bars for a given concentration is not significantly different from each other (Tukey's honest significant difference multiple range post hoc test $\mathrm{p}<0.05$ IBM SPSS version 25 ).

Table 1. Antibacterial activity of the pure compound (1) extracted from Grewia lasiocarpa stem bark (zone of inhibition $\mathrm{mm}$ ).

\begin{tabular}{|c|c|c|c|c|c|c|}
\hline \multirow{2}{*}{$\begin{array}{c}\text { Bacterial } \\
\text { strains }\end{array}$} & \multicolumn{5}{|c|}{ Concentration $(\mu \mathrm{g} / \mathrm{mL})$} & \multirow{2}{*}{$\begin{array}{c}10 \mu \mathrm{g} / \mathrm{mL} \\
\text { (positive } \\
\text { control) }\end{array}$} \\
\hline & 240 & 120 & 60 & 30 & 15 & \\
\hline MRSA & 6.50 & 6.50 & 6.50 & 6.50 & $\mathrm{R}$ & $12.33 \pm 2.31 *$ \\
\hline SA & $\mathrm{R}$ & $\mathrm{R}$ & $\mathrm{R}$ & $\mathrm{R}$ & $\mathrm{R}$ & $7.75 \pm 0.00 *$ \\
\hline PA & $\mathrm{R}$ & $\mathrm{R}$ & $\mathrm{R}$ & $\mathrm{R}$ & $\mathrm{R}$ & $13.55 \pm 3.24$ \\
\hline ST & $\mathrm{R}$ & $\mathrm{R}$ & $\mathrm{R}$ & $\mathrm{R}$ & $\mathrm{R}$ & $19.33 \pm 1.92$ \\
\hline KP & $\mathrm{R}$ & $\mathrm{R}$ & $\mathrm{R}$ & $\mathrm{R}$ & $\mathrm{R}$ & $14.22 \pm 3.77$ \\
\hline $\mathrm{EC}$ & $\mathrm{R}$ & $\mathrm{R}$ & $\mathrm{R}$ & $\mathrm{R}$ & $\mathrm{R}$ & $18.33 \pm 1.68$ \\
\hline
\end{tabular}

Note: R: resistant, SA: , Staphylococcus aureus (ATCC 25923), Methicillin-resistant Staphylococcus aureus [MRSA] (ATCC BAA-1683), PA: Pseudomonas aeruginosa (ATCC 27853), Salmonella typhimurium (ATCC 14026), KP: Klebsiella pneumoniae (ATCC 314588), EC: Escherichia coli (ATCC 25922), Positive control: Streptomycin $\left(10 \mu \mathrm{g} / \mathrm{mL}^{*}\right)$; Gentamicin $(10 \mu \mathrm{g} / \mathrm{mL})$ and $(n=3)$, N/A: Not applicable.
Table 2. IC50 values of compound (1) isolated from the stem bark of Grewia lasiocarpa, ascorbic acid (AA), and gallic acid (GA) used for the DPPH and FRAP assays

\begin{tabular}{ccc}
\hline Sample & DPPH $(\boldsymbol{\mu g} / \mathbf{m L})$ & FRAP $(\boldsymbol{\mu g} / \mathbf{m L})$ \\
\hline AA & $65.09 \pm 1.81$ & - \\
GA & - & $51.12 \pm 1.71$ \\
Compound 1 & $>1000$ & $>1000$
\end{tabular}

Note: The $\mathrm{IC}_{50}$ of the DPPH and FRAP assay of compound (1) isolated from the crude chloroform extract of the stem bark of Grewia lasiocarpa E. Mey. ex Harv. Data are presented as mean, $n=3$, of triplicate determinations. AA: ascorbic acid, GA: gallic acid 
Table 3. IC 50 values of lupeol on HEK293, HeLa and MCF-7 cell lines

\begin{tabular}{cc}
\hline Cell lines & IC $_{\mathbf{5 0}}$ value $(\mathbf{m g} / \mathbf{m L})$ \\
\hline HEK293 & ND \\
HeLa & $>1000$ \\
MCF-7 & $>1000$ \\
\hline
\end{tabular}

The results showed that the inhibition percentage of the ascorbic acid against free radicals DPPH was dosedependent; however, the inhibition percentage of compound (1) was not dose-dependent (Figure 3.A). The results of FRAP also have a similar pattern (Figure 3.B). The $\mathrm{IC}_{50}$ of ascorbic acid and gallic acid was $65.09 \pm 1.81$ $\mu \mathrm{g} / \mathrm{mL}$ and $51.12 \pm 1.71 \mu \mathrm{g} / \mathrm{mL}$ for DPPH and FRAP assays, respectively. The $\mathrm{IC}_{50}$ value of compound (1) was $\geq 1000 \mu \mathrm{g} / \mathrm{mL}$ (Table 2). This result was similar to Tchimene et al. (2016) that lupeol exhibited a more potent antioxidant activity at $800 \mu \mathrm{g} / \mathrm{mL}$, implying that if a higher concentration were used, the $\mathrm{IC}_{50}$ value would have been lower (Table 2). Thus, lupeol does not have a strong antioxidant activity at low concentrations. Besides, the application of other antioxidant assays such as ferrous oxidation-xylenol orange (FOX), $\beta$-carotene bleaching assay, 2,2'-azinobis (3-ethylbenzothiazoline-6-sulfonic acid) (ABTS), butylated hydroxytoluene (BHT), and ferric thiocyanate (FTC) assays might have resulted in a better antioxidant activity as acknowledged by Can-Cauich et al. (2019). This observation, therefore, suggests at least three antioxidant activity assays should be conducted to determine the antioxidant activity of a compound.

Compound (1) lupeol, exhibited dose-dependent cytotoxicity on two of the mammalian cancer cell lines used (Figure 4) which was similar to that reported by Lambertini et al. (2005) and Saleem (2009). Lupeol exhibited no significant cytotoxic effect on the HeLa and MCF-7 cell lines used, with $\mathrm{IC}_{50}$ values greater than 1000 $\mu \mathrm{g} / \mathrm{mL}$ (Table 3 ). Lupeol has cytotoxic activity against the HEK293 cell line; however, the $\mathrm{IC}_{50}$ of HEK293 was not determined because the cytotoxic activity exhibited was not dose-dependent (Table 3). The $\mathrm{IC}_{50}$ values $>1000 \mu \mathrm{g} / \mathrm{mL}$ of the antioxidant and cytotoxicity assays are suggestive that lupeol may exhibit weak activities at low concentrations.

In conclusion, we have confirmed and reported for the first time the presence of lupeol in the stem bark of Grewia lasiocarpa. Lupeol has indicated to have antibacterial and antioxidant activities, which was concentration-dependent. The results from the MTT cytotoxicity studies revealed that lupeol caused cell death in the HEK293, HeLa, and MCF-7 cells. However, the mechanism of cell death (apoptosis, etc.), still needs to be fully elucidated.

\section{ACKNOWLEDGEMENTS}

The authors would like to gratefully acknowledge the Organisation for Women in Science for the Developing World (OWSD) and Swedish International Development Cooperation Agency (SIDA) for their financial and intellectual contributions. The National Research Foundation (NRF) for the provision of consumables. Dr. Mrs. E.A. Ofusori, Dr. S.O. Bodede, Dr. N. Mahlangeni, Dr. K. Nagaraju, S. Shange, Dr. Nisar, and Mrs. F.O. Joshua for their assistance with the structural elucidation.

\section{REFERENCES}

Akwu NA, Naidoo Y, Singh M. 2019a. A comparative study of the proximate, FTIR analysis and mineral elements of the leaves and stem bark of Grewia lasiocarpa E. Mey. ex Harv.: An indigenous southern African plant. S Afr J Bot 123: 9-19. DOI: 10.1016/j.sajb.2019.01.028

Akwu NA, Naidoo Y, Singh M. 2019b. Cytogenotoxic and biological evaluation of the aqueous extracts of Grewia lasiocarpa: An Allium cepa assay. S Afr J Bot 125: 371-380. DOI: 10.1016/j.sajb.2019.08.009

Akwu NA, Naidoo Y, Singh M, Nundkumar N, Lin J. 2019c. Phytochemical screening, in vitro evaluation of the antimicrobial, antioxidant and cytotoxicity potentials of Grewia lasiocarpa E. Mey. ex Harv. S Afr J Bot 123: 180-192. DOI: 10.1016/j.sajb.2019.03.004

Alamgir ANM. 2017. Therapeutic use of medicinal plants and their extracts. Pharmacognosy. DOI: 10.1007/978-3-319-63862-1

Altemimi A, Lakhssassi N, Baharlouei A, Watson DG, Lightfoot DA. 2017. Phytochemicals: Extraction, isolation, and identification of bioactive compounds from plant extracts. Plants 6 (4): 42. DOI: $10.3390 /$ plants6040042

Amoussa AMO, Lagnika L, Bourjot M, Vonthron-Senecheau C, Sanni A. 2016. Triterpenoids from Acacia ataxacantha DC: Antimicrobial and antioxidant activities. BMC Complementary Altern Med 16: 284. DOI: $10.1186 / \mathrm{s} 12906-016-1266-\mathrm{y}$

Arung ET, Kusuma, IW, Suwinarti W. 2018. Identification and evaluation of bioactivity in forest plants used for medicinal purposes by the Kutai community of East Kalimantan, Indonesia. Biodiversitas 19 (1): 253-259. DOI: 10.13057/biodiv/d190134.

Badami S, Gupta MK, Ramaswamy S, Rai SR, Nanjaian M, Bendell DJ, Subban R, Bhojaraj S. 2004. Determination of betulin in Grewia tiliaefolia by HPTLC. J Separation Sci 27: 129-13. DOI: $10.1002 /$ jssc. 200301599

Bajoriniene A, Leitmeyer KC, Struelens MJ, Kokki MH. 2019. Investing in public health microbiology laboratories in Western Balkan Countries enhances health security from communicable disease threats in Europe. Front Public Health 7: 8. DOI: $10.3389 /$ fpubh.2019.00008

Balde E, Camara A, Traoré M, Baldé N, Megalizzi V, Pieters L, Balde A. 2019. The hypoglycemic and cytotoxic activity of the leave extract of Combretum glutinosum Perr ex DC. J Pharmacog Phytochem 8: 2230-2237.

Benzie IF, Strain JJ. 1996. The ferric reducing ability of plasma (FRAP) as a measure of "antioxidant power": The FRAP assay. Anal Biochem 239: 70-76. DOI: 10.1006/abio.1996.0292

Beserra FP, Xue M, Azevedo Maia, GLA, Rozza AL, Pellizzon CH, Jackson CJ. 2018. Lupeol, a pentacyclic triterpene, promotes migration, wound closure, and contractile effect in vitro: Possible involvement of PI3K/Akt and p38/ERK/MAPK pathways. Molecules 23: 2819-2835. DOI: 10.3390/molecules23112819.

Bhagat S, Misra G. 1974. Chemical constituents of Grewia rothii. Indian J Chem 12 (9): 1018-1019.

Boon R, Pooley E, 2010. Pooley's trees of eastern South Africa. Flora and Fauna Publications Trust, UK.

Braca A, Sortino C, Politi M, Morelli I, Mendez J, 2002. Antioxidant activity of flavonoids from Licania licaniae flora. J Ethnopharmacol 79: 379-381. DOI: 10.1016/S0378-8741(01)00413-5.

Can-Cauich CA, Sauri-Duch E, Moo-Huchin VM, Betancur-Ancona D, Cuevas-Glory LF. 2019. Effect of extraction method and specie on the content of bioactive compounds and antioxidant activity of pumpkin oil from Yucatan, Mexico. Food Chem 285: 186-193. DOI: 10.1016/j.foodchem.2019.01.153

Chattopadhyay S, Pakrashi SC. 1975. Studies on Indian medicinal plants. 34. Triterpenes from Grewia asiatica. Indian Chemical Society, India. https://agris.fao.org/agris-search/search.do?recordID=US201302767131 
Chen Q, Wang Q, Zhu J, Xiao Q, Zhang L. 2018. Reactive oxygen species: key regulators in vascular health and diseases. British J Pharmacol175 (8): 1279-1292. DOI: 10.1111/bph.13828

Cordell GA. 2015. Ecopharmacognosy and the responsibilities of natural product research to sustainability. Phytochem Lett 11: 332-346. DOI: 10.1016/j.phytol.2014.09.003

Da H, Gu XJ, Xiao PG. 2015. Medicinal Plants: Chemistry, Biology and Omics. Woodhead Publishing, UK.

Dwivedi BK, Manigauha A. 2017. In-vitro antioxidant and hepatoprotective effect of ethanolic fraction of the leaves of Grewia asiatica Linn. in rats. Asian J Pharm Pharmacol 3: 167-171.

Ghosh AK, Brindisi M, Shahabi D, Chapman ME, Mesecar AD. 2020 Drug development and medicinal chemistry efforts toward SARSCoronavirus and Covid-19 therapeutics. Chem Med Chem 15: 1-27. DOI: $10.1002 / \mathrm{cmdc} .202000223$.

Goyal PK. 2012. Phytochemical and pharmacological properties of the genus Grewia: A review. Intl J Pharm Pharm Sci 4: 72-78.

Gurupriya S, Cathrine L, Ramesh J. 2018. In vitro antidiabetic and antioxidant activities of lupeol isolated from the methanolic extract of Andrographis echioides leaves. J Pharmacog Phytochem 7: 768-775.

Jahan N, Makbul SAA. 2020. Phytochemical and pharmacological appraisal of barks from Unani medicinal plants. In Plant-derived Bioactives. Springer, Singapore. DOI: 10.1007/978-981-15-1761-7_22.

Jain P, Bari S. 2010. Isolation of lupeol, stigmasterol and campesterol from petroleum ether extract of woody stem of Wrightia tinctoria. Asian J Plant Sci 9: 163. DOI: 10.3923/ajps.2010.163.167.

Jaspers WJMM, Bashir AK, Zwerving JS, Malingre TM. 1986 Investigation of Grewia bicolor Juss. J Ethnopharmacol 17: 205. DOI: 10.1016/0378-8741(86)90109-1.

Jayasinghe U, Balasooriya B, Bandara A, Fujimoto Y. 2004. Glycosides from Grewia damine and Filicium decipiens. Nat Prod Res 18: 499502. DOI: 10.1080/14786410310001620538.

Lambertini E, Lampronti I, Penolazzi L, Khan MTH, Ather A, Giorgi G, Gambari R, Piva R. 2005. Expression of estrogen receptor $\alpha$ gene in breast cancer cells treated with transcription factor decoy is modulated by Bangladeshi natural plant extracts. Oncol Res Featuring Preclin Clin Cancer Ther 15: 69-79. DOI: 10.3727/096504005775082057.

Lobo V, Patil A, Phatak A, Chandra N. 2010. Free radicals, antioxidants and functional foods: Impact on human health. Pharmacog Rev 4 118. DOI: $10.4103 / 0973-7847.70902$

Kumari V, Kaushal K, Sharma AK, Mishra RC, Soni P. 2018. Some phytochemicals found in medicinal plants used in cancer-a review. Med Chem (Los Angeles) 8: 423-425. DOI: 10.4172/21610444.1000491 .

Ma C, Zhang HJ, Tan GT, Hung NV, Cuong NM, Soejarto DD, Fong HH. 2006. Antimalarial compounds from Grewia bilamellata. J Nat Prod 69: 346-350. DOI: 10.1021/np050313d.

Moradkhani S, Kobarfard F, Ayatollahi SAM. 2014. Phytochemical investigations on chemical constituents of Achillea tenuifolia Lam. Iranian J Pharm Res 13: 1049-1054.

Mosmann T. 1983. Rapid colorimetric assay for cellular growth and survival: Application to proliferation and cytotoxicity assays. J Immunol Method 65: 55-63. DOI: 10.1016/0022-1759(83)90303-4.

Oribayo O, Owolabi M, Ukpo G, Shode F. 2018. Antioxidant activity of some Nigerian medicinal plants used in malaria treatment. Trop J Nat Prod Res 2: 18-22. DOI: 10.26538/tjnpr/v2i1.4

Ogunlaja OO. 2017. Phytochemical, elemental and biological studies of three Ficus species (Moraceae) found in KwaZulu-Natal, South Africa. [Dissertation]. University of KwaZulu-Natal, Durban.

Papadopoulou P, Misseyanni A, Marouli C. 2020. Current environmental health challenges: Part I-exposures and research trends. In Handbook of Research on Emerging Developments and Environmental Impacts of Ecological Chemistry. IGI Global. DOI: 10.4018/978-1-79981241-8.ch001

Patel S, Srivastava S, Singh MR, Singh D. 2018. Preparation and optimisation of chitosan-gelatin films for sustained delivery of lupeol for wound healing. Intl J Biol Macromol 107: 1888-1897. DOI: 10.1016/j.ijbiomac.2017.10.056

Perez C, Pauli M, Bazerque P. 1990. An antibiotic assay by agar well diffusion method. Acta Biologiae et Medicinae Experimentalis 15: 113-115.

Pramodini G, Khasim SM, Alam P, Zaki S 2018. Evaluation of anthelmintic activity of ethanolic extract of Grewia flavescens Juss. whole plant. World J Pharm Pharm Sci 7 (4): 998-1003.

Saleem M. 2009. Lupeol, a novel anti-inflammatory and anti-cancer dietary triterpene. Cancer Lett 285: 109-115. DOI: 10.1016/j.canlet.2009.04.033

Sánchez-Burgos J, Ramírez-Mares M, Gallegos-Infante J, GonzálezLaredo R, Moreno-Jiménez M, Cháirez-Ramírez M, Medina-Torres L, Rocha-Guzmán N. 2015. Isolation of lupeol from white oak leaves and its anti-inflammatory activity. Industr Crops Prod 77: 827-832. DOI: $10.1016 /$ j.indcrop.2015.09.056

Shukla R, Sharma DC, Baig MH, Bano S, Roy S, Provazník IA, Kamal M. 2016. Antioxidant, antimicrobial activity and medicinal properties of Grewia asiatica L. Med Chem 12: 211-216. DOI: 10.2174/1573406411666151030110530.

Sidhu JS, Zafar TA. 2020. Fruits of Indian Subcontinent and Their Health Benefits. In Herbal Medicine in India. Springer, Singapore. DOI: 10.1007/978-981-13-7248-3_28

Silva ATM, Magalhães CG, Duarte LP, Mussel WN, Ruiz ALTG, Shiozawa L, Carvalho JE, Trindade IC, Filho, SA. 2017. Lupeol and its esters: NMR, powder XRD data and in vitro evaluation of cancer cell growth. Brazilian J Pharm Sci 53: e00251. DOI: 10.1590/s217597902017000300251

Sinha J, Purwar S, Chuhan SK, Rai G. 2015. Nutritional and medicinal potential of Grewia subinaequalis DC. (syn. G. asiatica.) (Phalsa). J Med Plants Res 9: 594-612. DOI: 10.5897/JMPR2015.5724.

Soujanya B, Kumar AK, Sreedhar M, Aparna K, Reddy KR. 2017. Quantification of lupeol in selected commercial coloured cultivars of mango (Mangifera indica L.) cultivated in Telangana Region. Int J Pure App Biosci 5: 2141-2146. DOI: 10.18782/2320-7051.5730.

Swargiary G, Rawal M, Singh M, Mani S. 2020. Molecular approaches to screen bioactive compounds from medicinal plants. In Plant-derived Bioactives. Springer, Singapore. DOI: 10.1007/978-981-15-1761-7_1.

Tchimene MK, Nwaehujor CO, Ezenwali M, Okoli CC, Iwu MM. 2016. Free radical scavenging activity of lupeol isolated from the methanol leaf extract of Crateva adansonii Oliv. (Capparidaceae). Intl J Pharmacogn Phytochem Res 8: 419-426.

Teoh JY, Hirai HW, Ho JM, Chan FC, Tsoi KK, Ng CF. 2019. Global incidence of prostate cancer in developing and developed countries with changing age structures. PloS One 14 (10). DOI: 10.1371/journal.pone.0221775

Thirugnanasambandan V, Kannayiram S. 2016. Antimicrobial and antioxidant properties of Grewia umbelliferea. J Harmonized Res Pharm 5: 95-106.

Ullah W, Uddin G, Siddiqui BS. 2012. Ethnic uses, pharmacological and phytochemical profile of genus Grewia. J Asian Nat Prod Res 14: 186-195. DOI: 10.1080/10286020.2011.639764.

Vithana MD, Singh Z, Johnson SK. 2019. Regulation of the levels of health-promoting compounds: Lupeol, mangiferin and phenolic acids in the pulp and peel of mango fruit: A review. J Sci Food Agric 99 (8): 3740-3751. DOI: $10.1002 /$ jsfa.9628.

Wal P, Wal A, Sharma G, Rai AK. 2011. Biological activities of lupeol. Syst Rev Pharm 2: 96-103. DOI: 10.4103/0975-8453.86298

Weekes LM. 2020. Improving Use of Medicines and Medical Tests in Primary Care. DOI: 10.1007/978-981-15-2333-5.

World Health Organization (WHO) 2011. Combat Antimicrobial Resistance. Word Health Day 2011. http://www.who.int/worldhealth-day/2011/WHD201_FS_EN.pdf. [11 May 2020].

Zia-Ul-Haq M, Shahid SA, Muhammed S, Qayum M, Khan I, Ahmad S. 2012. Antimalarial, antiemetic and antidiabetic potential of Grewia aslatica L. leaves. J Med Plants Res 6: 3087. DOI: 10.5897/JMPR12.028. 